\title{
マイクロプロセッサ応用の未来*
}

\section{石井 威望**}

\section{LSI の技術的意味}

半導体 (semiconductor), 特に LSI (large scale integration）がコンピュータを含めて，広く技術全体に大 きな影響を与え始めているてとは注目に值する．まず, その理由を考えてみたい.

すでに 1970 年以前から，集積回路 (IC, integrated circuit の略名）が実用化し, ある程度の集積度が達成さ れていたが，IC レベルの集積度ではまだまだ本格的な 応用商品が新しい市場を作り出すととはできなかった。

例えば，電子式卓上計算機（電卓）は文字どおり卓上 でしか使えない大きさであった，それが1970年代の前半 に LSI が使われるようになって，ポケットに入る大き さにまで小型化された. その結果, 完全に各個人がもつ という所有形態の質的変化が生じ，量的にも爆発的に拡 大した.

LSI 製造方法は，典型的な量産効果の特性をもって おり, 性能の向上にもかかわらず, 製造原価（1 個あた り）は低減する. この電卓の開発競争の中で, マィク ロ・コンピュータが誕生した。電卓に使用される LSI は専用(special purpose)のものであるが, マイクロ・コ ンピュータは汎用性 (general purpose) の LSI である.

すなわち，使用目的に応じてプログラムを変えるとと によって多目的利用が可能になった，別のいい方をすれ ば, マイクロ・コンピュータはハードウェアの観点から は LSI の量産効果をつルに利用しつつ, ソフトウェア の融通性を兼備するてとによって, 多品種少量生産の製 品にも応用可能になったのである.

* 昭和 55 年 11 月 7 日受付

** 東京大学 工学部産業機械工学科

Dept. of Mechanical Engg., Faculty of Engg., Univ. of. Tokyo.
LSI 技術がもたらした重要な変化は，それがきわめて 安定 (stable) しており, 信頼性 (reliability) が高く, 取り扱いが容易であるため, 特にマイクロ・コンピュー 夕は電子工学の専門家以外の技術者や, 場合によっては アマチュアにまで普及していったてとである．ての傾向 は，今後いっそう加速するであろう.

LSI の安定性を示す典型的な実例としては, 市販のマ イクロ・コンピュータを, 自動車に車載 (on board) し ても全く故障せず, 長期間安定に動作するし, 野外で使 用してもほとんどトラブルはない. とのため, 研究室 (laboratory) や工場の生産現場へ多数分散配置しても, 保守 (maintenance) 上ほとんど特別の配虑をする必要 もなくなった.

一言でいえば，実用性が向上し，過酷な使用条件でも 耐えられるので，応用分野が筫量ともに飛躍的に拡大し たととにほかならない。

上に述べた LSI 普及の理由のすべてに共通する点は， IC から LSI への集積度向上があるクリティカルなレベ ルを突破できたてとを意味している。

すなわち, 小型化においては, ポータブルというとュ ーマン・スケールに入ったてと, 所有形態が各個人ベー スになり量産規模が確保されて篤異的低価格が実現した とと, さらにプログラマブルな汎用性をもつマイクロ・ コンピュータが従来のコンピュータの最下限を引き下げ たとと，そして信頼性や安定性が非専門家で十分な水準 にまで達したてとなどである.

現在, 産業のあらゆる技術分野で雪崩を打って LSI が浸透し始めたのは，まさにあるクリティカルな限界が LSI によって破られたてとを意味している.

\section{LSI 応用の “新しい機械”}

日本産業はきわめて敩しい技術競争によって，そのバ 
イタリティを保っている。したがって，LSIがあるレべ ルに達したてとがわかると，強いレスポンスを示した。 すなわち，各企業は LSI をいかに早くかつ適切に自社 の製品の中に組み込んで競争に生き残るかが死活問題で あると真剣に考え出した。

特に従来電子工学と無縁であると考えられていた分野 においては，混迷と不安と希望が入りまじった複雑な状 況がみられる．例えば，時計にディジタル電子時計とい う新商品分野が加わり, 電卓メーカーがての産業へ参入 してきた. 古い精密機械技術の歴史をもつ在来の時計メ 一カーも LSI を導入して防戦せざるをえなかった。ま た電卓自体が時計機能を兼社備え，名刺大のカード型の 新商品を戦列に加えてきた. 家庭電気製品, ミシンなど 日常生活の中に LSI がふんだんにちりばめられるの は,もう時間の問題である.

その中で最大のインパクトをもつものに，自動車があ ろ. 自動車工業が機械的技術（mechanics）の粋を結集 した，典型的量産商品であることはいうまでもないが， 今まで全然エレクトロニクスと断絶していたわけではな い. カー・ラジオやカー・ステレオはもちろん, 照明, エアコンディションや各種の電動モーターとその電源な どが，かなり以前から装備されてきた。

またICが出現したてろにも, 自動車電子工学 (automotive electronics) が本格化するのではないかと期待 されたことがあったけれども，遂に不発に終わった。

その原因は前節でも述べたように，まだIC ではある クリティカルな限界に達しえなかったといってよかろ う. IC 程度のことは純機械的技術でも結構カバーでき る場合も多く，ときにはよりスマートな解決さえでき た.

しかし，LSI のレベルになると機能上，もはや純機械 的技術では決して対抗しえない複雑な論理回路や大量の 記境容量 (memory capacity) を駆使した装置が実現で きる.すでに, 現在の自動車にも, アンチ・スキッド, EFI (electronic fuel injection), クルーズ・コンピュー タ (cruise computer) などが実用化しているばかりでな く,さらに, EAT (electronic automatic transmission), 電子キーロック，マイコン・シート（microcomputer controlled aiustable seat) などが実用化の過程にある.

しかし，LSI の影讋が本格的に自動車で顕在化するの は，まさにてれから始まると考えられる．現在までは， むしろそのリハーサル程度にすぎない。

自動車工業は最も競争が激烈な分野であり，最も巨大 な組立工業であるから，LSIが量産志向をもち，現在技 術進歩が著しいてととは完全に双方の要求は合致する.
エネルギー問題，安全対策などの自動車技術が当面する 課題の解決にも LSI は不可欠の要素になるに違いな い.

もちろん，自動車以外の機械にも LSI の影響はます ます強くなり, それは不可逆的な現象として定着し，技 術文明の歴史上に “新しい機械” の時代を画するととに なるのではあるまいか.

この “新しい機械”は，構造部材とエネルギーとある 程度の制御機能から構成されていた従来の “古い機械” からは格段に進歩したものであり, 高度の制御機能例え ばコンピュータ類似 (computer-like) の部分の比重がき わめて重くなるであろう．例えば，工作機械 (machine tool) は最近 NC (numerical control) の型式のものが 増加し, さらに CNC (computerized NC) へと戦略的 中心が移行している.

また, CAM (computer aided manufacturing) とか, FMS (flexible manufacturing system) が最近のトピッ クスであるという事実からも容易に理解されるように, まさに “新しい機械” へと進化 (evolution) をしつつあ る. ての場合， LSI の影幚は直接かつ決定的である.

\section{3. ロボットとその周辺}

“新しい機械” の代表的な一例として, 産業用ロボッ トがある. 現在の水準では，まだ視覚や聴覚に相当する センサー (sensor) 機能や, 四形や言葉を認識する (recognition) 能力に乏しく，もっぱら反復作業（play back）が実用の中心であるが，実験的には高度なロボッ トがテストされている．乙の場合にも，LSI とりわけマ イクロ・コンピュータの役割は絶対的である.つまり， ロボットの神経系統 (nerve network) として不可欠で ある.

LSI が情報処理 (information processing) や通信 (communication) にどれほど重要な役割を果たすかと いうことは，ててに改めて強調するまでもあるまい。そ れは人類社会における，一種の神経組織に相当する機能 である. LSI なくしては, 超大型コンピュータを製作 するてとはできない.

ロボットのセンサーに相当する部分は, 情報処理や通 信のシステムでは情報の入力チャンネルすなわちマン・ マシン・インターフェイスと呼ばれている部分である. 一般的にいえば，情報の形としては画像や図形や音声で もよいはずであるが，実用的にはもっぱら記号化された 情報，それも 2 進法的コード (binary code) が使用さ れている。 
しかし，LSIがようゃくその制限を取り除き始めてい ろ. 例えば, 音声による入力は10年前にはほとんど実用 化のメドが立たなかったが，LSIによって今や実用直前 の段階に到達した。

図形のパターン認識（pattern recognition）について も，マイクロ・コンピュータが実用化を促進しているの であるが, 単に入力の問題にとどまらず出力の問題にも LSI が決定的な役割を果たしつつある. 図形ないし画像 処理(image processing) 之呼ばれている分野で，特に漢 字のような象形文字 (ideogram) は重要であり，1980年 代に日本では LSI によって漢字の入出力ないしワード プロセッシング (word processing) が実用化すると予 測される.アルファベット（表音文字）に比較すると， 大幅に遅れていた漢字の使用が情報処理と直結した場合 の効果は計りしれないほど大きい。

音声出力についても， LSI は在来のコンピュータか らの音声出力よりも，格段に低価格にできるばかりでな く, ROM (read only memory) にあらかじめ封入さ れた，いわば “音のかん詰”を利用する方式は現在始ま ったばかりであるが， LSI の進歩に伴い広い応用範用 をもつようになるであろう.

例光ば, 自動車運転中に音声で通報する方式とか, 語 学の翻訳や練習などは比較的早く普及するような状勢で ある.さらに TV ゲームなどのような画像と同時に出 力する, 娱楽方面への応用も LSI に依存している.

\section{4. 情報化と分散化}

LSI が技術全体に影響を与え，産業構造を変革し，さ らに都市計画や国土全体の計画へも影響すると予想され ている. 同時に社会全体のシステム構造原理（structural principle of system) を集中化志向 (centralization oriented) 加ら分散化志向 (decentralization oriented) 亿変 化させる働きもする.

まず産業構造の変化とは，前節までに述へたように， “新しい機械”による“新しい機械” の生産, つまり自 己増殖的連鎖反応である.

すでに，最新鋭のコンピュータ工場ではそのパターン が現実に始まっている。てれは，ロボットによるロボッ トの生産ともいえる．また，武行錯誤まで含めた研究開 発ロボットの活動によって, より高次の研究開発ロボッ トが進化的（evolutionary）に製作されるならば，“新 しい機械”の時代は，より高次化するてとになり，おそ らく人類が初めて経験する事態であり，現在生物におけ る DNA (deoxy ribo nucleic acid) の挙動 (behavior)
と考えられている原理とほとんど同一である.

このような DNA 複製過程 (DNA duplication process）および新しい機械の自己増殖的特徵は，LSI の製 造や書籍の印刷などと共通する点がある。それれは，すべ て本貿的には情報の複製伝播 (duplication and propagation）にほかならない。

“情報化社会”論が唱えられてから，早くも十余年経 ているが, 産業構造の変化の本質は, ての情報化社会 （information society） そのものであり，通常産業の高 度化, 知識集約化, 先端型技術産業化などの呼び名が与 えられている事柄である.

しかし，LSI の登場までは，言葉や概念のみが先行 し, 一人歩きしており, ハードウェアとしての実態が対 応しなかった恨みがあった。 その意味では，LSIの確立 こそ分子生物学における DNA 分子構造の確立と対比す べき，工業化社会から情報化社会へ移行させる決定的な 出来事 (event) である.

次に，分散化志向と LSI の関係について述べょう.

産業の現場においては，LSI あるいはマイクロ・コン ピュータの普及とともに，現実として分散化システムが 採用されるようになっている，LSIが実在しなかったた めに集中化システム以外は作るてとができなかったとい うのが実情である。 そして LSI に対応する“新しい機 械”や情報化社会は，本質的に分散的傾向をもってい る. 集中化によって得られた規模の効果 (scale merit) が，分散化によって失われても分散化によって得られる メリットがより大きいのである.

分散化のメリットとは何か。一般にシステムを構成す る各部分は，それぞれユニークな特殊性をもっている。 つまり多様性（variety）の存在であり, 各部分のもつ自 由度である. 分散化は本質的に多様性のもつポテンシャ ルをフルに発揮させることをねらっている．集中化の規 模の効果は, 全体に共通する画一的な横断的な底辺層を なるべく広域に集めるととによって成立する。 ての場 合, 各部分の共通的でない部分は残されてしまい, 多樣 性は眠れる資源に化してしまう。

産業構造の高度化とか知識集約化，あるいは先端的技 術産業化などが表現しようとしているのは，システム全 体の底辺に共通する画一性汃らの脱却にほかならない。 つまり，多様性にウエイトをおくというととである。

工業化社会においては, 画一的量産こそ戦略目標であ った．皮肉なととに，量産技術の極致ともいうべきLSI 製造の結果，その LSI 自体が工業化社会から情報化社 会への移行を促進し，多様性を生かす分散システムを可 能にしているのである. 
集中化と分散化は概念としては対立するが，システム 全体の共通部分を集中化し, 各部の多梯性は分散化シス テムにまかせるという二者共存が，少なくとも日本人に とっては最も現実的解決であることが多い.

\section{5. 日本産業のマイクロ・コンピュータ に対する受容性 (acceptance)}

上に述べたとおり，分散化は多様性いい換えれば個性 的になるととである.

例えば，時計を例にとれば町中が教会の時計(鐘の音) でいっせいに行動していたときに比へて，各家庭に置き 時計があるようになると，それぞれ独自のスケジュール が可能になる.さらに個人が腕時計をもつようになれ ば，個人の時間はますます有効に使うことができる。も ちろん, 時計の数が増加すれば全部の時計の時刻を合わ せるためには，ときたま教会の鐘もならす必要があるか もしれない，LSIの普及は，ちょうど個人が腕時計をも つようになった状態に似ている。

独特な日本の雇用体制においては，企業にとって各従 業員の能力発揮こそ最大の関心事であり, 事実それに成 功している.

LSI の普及は上述のとおり, 分散化と多様性者促進 し，各個人の能力を高める働きをする，したがって，日 本企業はマイクロ・コンピュータのプログラムなどへ従 業員の創意工夫を注入し，きめ細かく多樣性を吸収して いく方向つまり分散化と情報化一向かうに違いない，少 なくとも日本においては，てのような民間主導型で “新
しい機械”の時代が始まっていくであろう.

しかし，てのことは各企業が外国に対して排他的な競 争力を培養し，再び貿易摩擦を引き起てすととを意味す るものではない，製品の多様性を LSI やマイクロ・コ ンピュータの付加によって達成しょうとする場合, “新 しい機械”の時代には国際的技術協力が不可欠になるで あろう。

なぜならば，多様性に国際化を含めて市場の広域化が 行われる場合に，“新しい機械”は，画一的な工業化社 会の製品と異なり，ハードウェアよりソフトウェアの比 重が支配的になる.すでにコンピュータにおいてはそう なっている．製品の高度化はソフトウェアの比重の上昇 とパラレルである.

一方, ソフトウェアはきわめて各国の文化や風習に強 く支配される.言語の違いなどはその第一にあげられる 実例である、したがって，それぞれの国の技術者でなけ ればよいソフトウェアは作れない。このために，日本企 業は上述のマイクロ・コンピュータの普及を社内で推進 すると同時に，国際的な技術協力を熱心に実行するであ ろう.

すなわち，国際協力をどのように進めるかというとと が，企業間競争の重要なファクターになる，上き技術的 パートナーとは，よきソフトウェアを相互に交換し合え る仲間でなければならない。

以上のととは，当然企業間レベルを基礎にして，その うえに国家レベルでの協力関係と共存共栄へと発展して いく性質のものでなければならない. 